\title{
A race-based detour to personalized medicine
}

$\mathrm{F}$ ew experts in medical genetics would argue that June 23, 2005 wasn't an important day. Consensus on whether it was a good or bad day is another matter. Some claim a major step on the long road to personalized medical care was taken. Others are far less convinced, suggesting it was the day the United States government decided, unwisely, to push the field of medical genetics into the heated realm of racial politics.

On that date, the US Food and Drug Administration (FDA) approved, for the first time, a drug for a specific race, to wit, the fixed-dose combination drug isosorbide dinitrate and hydralazine (BiDil) for use as a heart disease medication within the black population, who have a much higher risk of heart failure than whites.

Supporters of the product, which included the National Association for the Advancement of Colored People, claimed that targeting an ethnic population that needed a drug the most and responded well to it made sense - that it was progress in the field of pharmacogenetics, which aims to increase the efficacy and safety of medications by tailoring them to individuals. The practice of medicine should not be colourblind, they argued, and to oppose a drug for use strictly by blacks was worse than political correctness run amok - it was yet another blow to a population that already struggles to access high-quality health care.

The licensing of isosorbide dinitrate/hydralazine thus became a turning point in discussions on the merits of race-based medicine, a debate that continues to rage. Critics of race-specific therapies argue that focusing on genetics rather than on social and economic inequalities will not reduce disparities in health outcomes and access to care among different ethnic groups. Furthermore, they say, race is a social, rather than a biological, construct.

"Using race is a bad proxy for genetic ancestry," says Althea Grant, chief of the

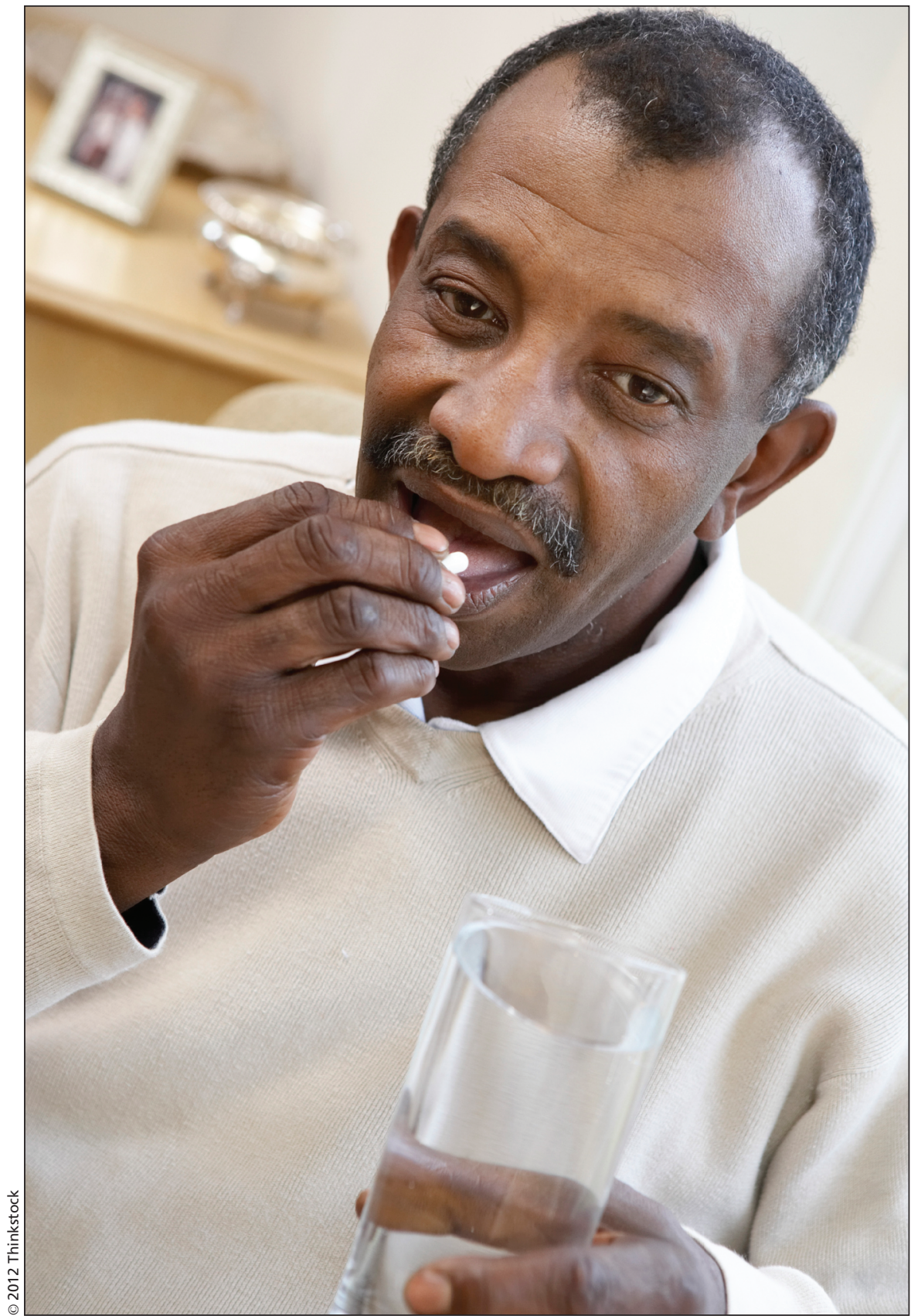

Critics of race-specific therapeutics argue that race is not a genetic construct, but rather a social one.

Epidemiology and Surveillance Branch, Division of Blood Disorders, National Center on Birth Defects and Developmental Disabilities, at the US Centers for Disease Control and Prevention.

This opinion is shared by one of the world's most famous geneticists: Craig Venter, the genetics pioneer who led the team that first sequenced the human genome in 2001. He has referred to the use of race and ethnicity in medical genetics as a crude tool and a personal 
pet peeve, suggesting that it will no longer be necessary once the price of sequencing genomes falls to an amount that would make it reasonable to sequence everybody's genome, a figure he pegged at US $\$ 1000$.

Venter even submitted his own DNA for comparison with that of another white male to illustrate his point ( $\mathrm{J}$ Clin Pharm Ther 2008;84:306-9). "Their genetic differences underscore the importance of personalized genomics over a race-based approach to medicine," the paper states. "To attain truly personalized medicine, the scientific community must aim to elucidate the genetic and environmental factors that contribute to drug reactions and not be satisfied with a simple race-based approach."

The first problem with using race in medical genetics is determining which races constitute a part of someone's background. Few people have extensive knowledge of their ancestral lineage, and skin colour and other external markers don't tell the full story. Even people who are aware of their mixed heritage often place themselves in one camp - or are put there by others. Prominent examples include US President Barack Obama and professional golfer Tiger Woods, who are often referred to as black even though the former has a white mother and the latter's mother hails from Thailand.

"People tend to self-identify with a particular race more than another even if there is a mix," says Grant. "They might not even know all the ancestries that are in the mix."

In some areas of medicine, using race as a screening tool has already been shown to create problems, both practical and ethical. That's why states abandoned the practice of screening only black newborns for hemoglobinopathies, such as sickle cell disease, Grant and colleagues concluded (Ethn Health 2011;16:37788). The state of Georgia, the last holdout for ethnicity-based newborn screening, discontinued its use in 1998.

More practically, sorting out who should be screened was less efficient than providing it to all newborns. There was also a "social distaste and potential legal liability" for missing cases outside the targeted group, the paper noted.

Prenatal screening based on race, however, remains commonplace. US health care provider Kaiser Permanente, for instance, offers ethnicitybased genetic screening for expectant mothers, recommending tests for hemoglobin E for those with Southeast Asian backgrounds, tests for sickle cell diseases for those of black descent, tests for cystic fibrosis for those with European backgrounds and tests for Tay-Sachs disease for those with ties to the Ashkenazi Jewish population.

"With prenatal screening, it's not really about early intervention. It's about family planning. If you don't test prenatally, the possible consequence is that you may have an affected child and not know ahead of time. That's not as severe a consequence as failing to provide treatment to a newborn," says Grant. "Still, it's unfair for people not to have equal knowledge."

Another concern sometimes raised about race-based medicine is that it could be interpreted as implying one race is genetically inferior to another. Some suggest that was the case with the clinical trial of isosorbide dinitrate/hydralazine, which enrolled only participants who self-identified as blacks. Others note that most drug trials are dominated by test subjects who are white, but the products aren't marketed as "white" drugs because the participants are considered to represent the entire human race.

"By approving BiDil only for use in black patients, the FDA emphasized the supposed distinctive, and substandard, quality of black bodies," Dorothy Roberts, a law professor at Northwestern University in Chicago, Illinois, wrote while denouncing race-based medicine (Minn J L Sci \& Tech 2011;12:1-21). "It sent the message that black people can't represent all of humanity as well as white people can."

Others fear that drug companies are exploiting race to market new products and that people outside a targeted group will be forced to use the drugs off-label, and pay more for them. Notably, in the case of isosorbide dinitrate/hydralazine, it was originally presented to the FDA as a medication for the general population but it failed to gain approval on that basis.

"If we go back to its origins, we find that BiDil did not begin as an ethnic drug. Rather it became ethnic over time and through a complex array of legal, com- mercial, and medical interventions, that transformed the drug's identity," wrote Jonathan Kahn, a law professor at Hamline University in Saint Paul, Minnesota (www.councilforresponsiblegenetics.org /pageDocuments/PLMVM6FTAO.pdf). Unlike "racialized medicine, which treats race as genetic, the use of race in medical practice has many legitimate and important places. Collecting broad-based epidemiological data is perhaps foremost among these. Only by using social categories of race is it possible to identify and track racial disparities in health, health care access and outcomes."

A contributing factor to the racial disparity in accessing health care, in addition to the social and economic causes, is a lingering distrust of the health care system within some ethnic groups. The black population in the US, for one, has good reason to be leery, having often suffered medical abuses, such as the 40year experiment in Tuskegee, Alabama in which researchers told poor, rural black people that they were being treated for "bad blood" when in fact they were test subjects for untreated syphilis. Participants received meals, medical tests and burial insurance, but were never offered any form of treatment.

"They still have a high level of mistrust in the medical system," says Sandra Suther, associate professor of behavioural science and health education at Florida A\&M University in Tallahassee. "When you have that, plus concerns of invasion of privacy around genetic testing, it compounds matters."

Blacks in America, as well as Latinos, are also less likely to use genetic testing because many are unaware of its existence, Suther has concluded (Genet Med 2009;11:655-62). Both ethnic groups also tend to have less private health insurance and thus, less access to expensive genetic tests. Even if such tests were available, some blacks might refuse them as an attempt to further stigmatize their community. Talks on the benefits of genetic testing that don't take culture and history into consideration can veer off into accusations of labelling people as biologically inferior, Suther says.

"It can stir up a whole hornet's nest. It depends on how you present it," adds Suther, who suggests that communication and social issues will have to be 
resolved to ensure that the benefits of genetic medicine are provided to all ethnic groups. "We get excited about new medications and technologies, but we have to stop and think that this is not solving the other part of the problem. People need to have access. Let's make sure that all these wonderful genetic technologies will not widen that disparity." — Roger Collier, CMAJ

CMAJ 2012. DOI:10.1503/cmaj.109-4133
Editor's note: Fourth of a multipart series on genetic testing.

Part 1: Separating hype from reality in the era of the affordable genome (www.cmaj.ca/lookup/doi/10.1503/cmaj.109-4143).

Part 2: Popping the genetics bubble (www.cmaj.ca/lookup/doi/10.1503/cmaj .109-4142).

Part 3: Who should hold the keys to your DNA? (www.cmaj.ca/lookup/doi /10.1503/cmaj.109-4141).

Part 5: Race and genetics in the doctor's office (www.cmaj.ca/lookup/doi /10.1503/cmaj.109-4134). 